\title{
Influence of Nozzle Pressure on Performance and Emission in Compression Ignition Engine Running on Distilled Waste Plastic Oil (DWPO)
}

\author{
Chumsunti Santaweesuk and Adun Janyalertadun
}

\begin{abstract}
This paper presents the physical characteristics of distilled waste plastic oil (DWPO) with diesel fuel. And experiment in influence of nozzle pressure on performance and emission in compression ignition engine running on distilled waste plastic oil (DWPO). The performance test of compression ignition engine running with these oils also has been tested. The physical characteristics are Gross calorific value (MJ/kg), Kinematic viscosity, cst @ $40^{\circ} \mathrm{C}$, Specific Gravity@15.6 ${ }^{\circ} \mathrm{C}$, Cetane index, Flash point, ${ }^{\circ} \mathrm{C}$ Distillation temperature, ${ }^{\circ} \mathrm{C} @ 90 \%$ and distillation test. The performance, using Four-stroke, CI, direct injection, single cylinder 709 C.C., at standard nozzle pressure and setting nozzle pressure at 170,190 and 210 bar has been tested with in brake thermal efficiency, brake specific fuel consumption and exhaust gas emissions. The results show that physical characteristics of distilled waste plastic oil (DWPO) similar to diesel oil. Furthermore the performance of the engine, which is run by that nozzle pressure and oil are in good condition. When the experiment in influence of nozzle pressure on performance and emission in compression ignition engine running on distilled waste plastic oil (DWPO) be similar to commercial diesel.
\end{abstract}

Index Terms - Distilled waste plastic oil, compression ignition engine.

\section{INTRODUCTION}

Plastics are non-biodegradable polymers mostly containing carbon, hydrogen and few other elements. According to the survey conducted in 2009, All countries of Thailand has a quantity of 15.11 million ton (41,410 ton per day) solid waste generated. The recycle wastes are about $30 \%$ of total solid wastes and have portions of plastic wastes (PWs) about $16.8 \%$. From the total of 2.5 million tons of PW, most of these PWs are disposed to landfills and only are recycled from landfills approximately $3 \%$ by scavengers [1]. Attention is also focused on using oil derived from waste plastics in diesel engines. Diesel engines are the most preferred power plants due to their excellent driveability and higher thermal efficiency [2]. Despite their advantages, they emit high levels of oxides of nitrogen (NOx) and smoke which will have an adverse effect on human health. Hence emissions are normally stringent and the depletion of petroleum fuels has necessitated the search for alternate fuels for diesel engines. In the efforts to achieve the reduction of engine emissions and fuel consumption while keeping engine performance at an acceptable level, the fuel injection system plays an

Manuscript received January 11, 2013; revised March 14, 2013.

The authors are with Department of Mechanical Engineering, Faculty of Engineering, Ubon Ratchathani University, Ubonratchathani, Thailand (E-mail address: chumsunti@yahoo.com). important role. It is possible to predict to some extent the engine performance based on injection characteristics. The most important injection characteristics are injection pressure, injection duration and injection timing. The injection process influences the harmful NOx and smoke emissions.[3] The objective of this research is to study the influence of nozzle pressure on performance and emission in compression ignition engine running on distilled waste plastic oil.

\section{Source of Distilled Waste Plastic Oil as ALTERNATE FUEL}

The pyrolysis plant (Warinchamrap municipality, Thailand) is operated using a rotary kiln reactor with silica-alumina as a catalyst. In addition, the commercial filler, mainly consisting of kaolinites (china clay), was mixed with the catalyst. In each batch, the catalyst and commercial filler was filled up about 3\% of the input of MPWs (by wt $\%$ ). The amount of the catalyst and filler were about $30 \%$ and $70 \%$ of the mix (by $w t \%$ ). In addition the calcium hydroxide $\left(\mathrm{Ca}(\mathrm{OH})_{2}\right)$ was filled up in the reactor about $1 \%$ of the input of MPWs (by wt $\%$ ) for buffer and $\mathrm{HCl}$ absorber. The MPWs were fed and burned in the reactor. Briefly, these MPWs are burned up to $350-450{ }^{\circ} \mathrm{C}$ by LPG burner in atmospheric pressure. And then they are maintained with long lapses in time or the retention time at $380-450^{\circ} \mathrm{C}$ for about $6-8$ hours. In a typical run, the reactor is heated without oxygen. The gaseous products are condensed to liquid oil in a condenser tank at $25-30^{\circ} \mathrm{C}$. When the liquid fractions cool down, they reform to the pyrolytic oil (PO). The pyrolysis process involves the breakdown of large molecules to smaller molecules. Produces hydrocarbons with small molecular mass (e.g. ethane) that can be separated by fractional distillation and used as fuels and chemicals. This process gives a weight basis of $75 \%$ in liquid hydrocarbon, which is a mixture of petroleum, diesel and kerosene, 5\% to $10 \%$ residual coke and the rest is gas. Petroleum refineries are a separate species based on temperature. Temperature uses a splitter. Petroleum in the temperature range $250-350{ }^{\circ} \mathrm{C}$ was studied.

\section{EXPERIMENTAL SETUP}

The engine tests were conducted on a four stroke, compression ignition, water cooled, single cylinder, change speed diesel engine in Table I specifications of the engine.[4] The schematic diagram of the test setup is given in Fig. 1 An electrical dynamometer was used to load the engine. An air box was fitted to the engine for airflow measurement. The fuel flow rate was measured on volumetric basis using a 
burette and a stopwatch. Chromel alumel thermocouple in conjunction with a digital temperature indicator was used to measure the exhaust gas temperature, water cooled and room temperature. An exhaust gas analyzer was used to measure $\mathrm{NO}_{\mathrm{x}} / \mathrm{CO} / \mathrm{CO}_{2}$ emissions in the exhaust. The experiments were conducted at the rated engine speed of 1000 to $3000 \mathrm{rpm}$ All the tests were conducted by starting the engine with diesel only. Then the engine was run with distilled waste plastic oil (DWPO).

TABLE I: SPECIFICATIONS OF THE ENGINE [4].

\begin{tabular}{|l|l|}
\hline Engine parameter & Specification \\
\hline Make of model & Kubota RT140 plus \\
Engine type & Four-stroke, CI, direct \\
& injection, single cylinder \\
Bore x Stroke & $97 \times 96 \mathrm{~mm}$. \\
NO. of cylinder & 1 \\
Piston displacement & $709 \mathrm{cc}$ \\
Maximum power output & $10.3 \mathrm{kw} / 2400 \mathrm{rpm}$ \\
Continuous power output & $9.2 \mathrm{kw} / 2400 \mathrm{rpm}$ \\
Maximum torque & $5 \mathrm{~kg}-\mathrm{m} / 1600 \mathrm{rpm}$ \\
Compression ratio & $18: 1$ \\
Nozzle opening pressure $\left(\mathrm{kg} / \mathrm{cm}^{2}\right)$ & 150 \\
Retarded injection timing $\left({ }^{\circ} \mathrm{CA}\right)$ & $17.5 \mathrm{BTDC}$ \\
& \\
\hline
\end{tabular}

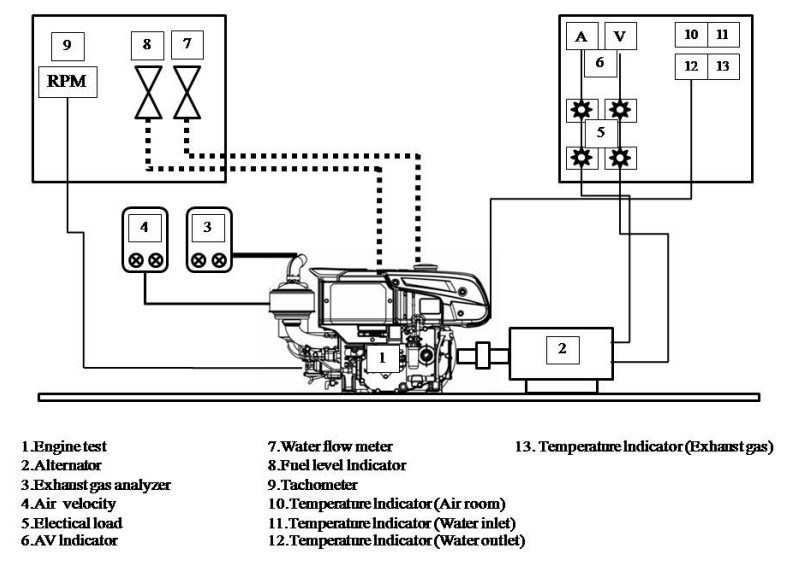

Fig. 1. Schematic of the engine test

\section{RESUltS AND Discussions}

TABLE II: PROPERTIES COMPARISON OF WASTE Plastic OIL AND Diesel.

\begin{tabular}{|l|c|c|c|}
\hline \multicolumn{1}{|c|}{ Properties } & $\begin{array}{c}\text { waste } \\
\text { plastic } \\
\text { oil }\end{array}$ & $\begin{array}{c}\text { Diesel } \\
\text { commercial }\end{array}$ & $\begin{array}{c}\text { Standard } \\
\text { test method } \\
{[5]}\end{array}$ \\
\hline Gross calorific value (MJ/kg) & 46 & 45.5 & ASTM D240 \\
Kinematic viscosity, cst @ & & & \\
$40^{\circ} \mathrm{C}$ & 2.085 & 3.162 & ASTM D 445 \\
Specific Gravity@15. $6^{\circ} \mathrm{C}$ & 0.802 & 0.834 & ASTMD1298 \\
Cetane index & 52 & 55 & ASTM D 976 \\
Flash point, ${ }^{\circ} \mathrm{C}$ & 80 & 75 & ASTM D 93 \\
Distillation temperature, ${ }^{\circ} \mathrm{C} @$ & & & \\
$90 \%$ & 350 & 355 & ASTM D 86 \\
\hline
\end{tabular}

\section{A. Characteristics and Distillation Tests}

Fig. 2 compares the Thermal and physical characteristics of distilled waste plastic oil (DWPO) and diesel of their distillation curves are very important. Therefore, characteristics of the produced distilled waste plastic oil (DWPO), which are Gross calorific value $(\mathrm{MJ} / \mathrm{kg})$, Kinematic viscosity, cst @ 40 $\mathrm{C}$, Specific Gravity@15.6 $\mathrm{C}$, Cetane index, Flash point, ${ }^{\circ} \mathrm{C}$ Distillation temperature, ${ }^{\circ} \mathrm{C} @$ $90 \%$ and distillation test results were given in Table I and Fig. 2 , respectively. They were discussed and compared with those of typical diesel fuel used in this study. The thermal and physical characteristics are shown in Table II. It is clear in the table that they are reasonably closer to the values of standard diesel fuel. One of the most important characteristics is gross calorific value, which is calculated as $46 \mathrm{MJ} / \mathrm{kg}$ by using measurement values. It is closer to gross calorific value of diesel fuel with a value of $45.5 \mathrm{MJ} / \mathrm{kg}$ in Thailand. In order to see whether the distilled waste plastic oil (DWPO) sample can be used efficiently in compression ignition engine, it is also necessary to examine and analyze the performance and exhaust emission results after using the sample in compression ignition engine. These results are given in the following sections and explained briefly.

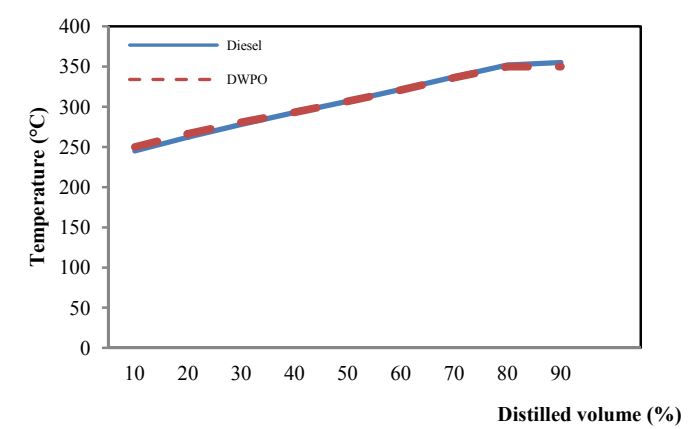

Fig. 2. Distillation chart of the distillaed waste plastic oil (DWPO) and diesel oil

\section{B. Brake Thermal Efficiency}

Fig. 3 Compares the influence of nozzle pressure in compression ignition engine running diesel oil and distilled waste plastic oil (DWPO) with standard nozzle pressure and setting nozzle pressure at 170,190 and 210 bar on brake thermal efficiency. It can be observed that the brake thermal efficiency is $28.25 \%$ at higher engine speed for diesel with standard nozzle pressure and can be observed that the engine running with distilled waste plastic oil (DWPO) at standard nozzle pressure and setting nozzle pressure at 170,190 and 210 bar gives brake thermal efficiency is $28.84 \%, 27.95 \%$, $30.10 \%$ and $27.95 \%$ respectively at full load. And average of the brake thermal efficiency is $25.71 \%$ at higher engine speed for diesel with standard nozzle pressure and with distilled waste plastic oil (DWPO) at standard nozzle pressure and setting nozzle pressure at 170,190 and 210 bar gives average brake thermal efficiency is $23.33 \%, 24.55 \%, 24.27 \%$ and $24.38 \%$ respectively. This result is a lower average in brake thermal efficiency for distilled waste plastic oil (DWPO) but increase average when setting nozzle pressure at 170,190 and 210 bar. Because of the changes in setting nozzle pressure cause can better oil spray.

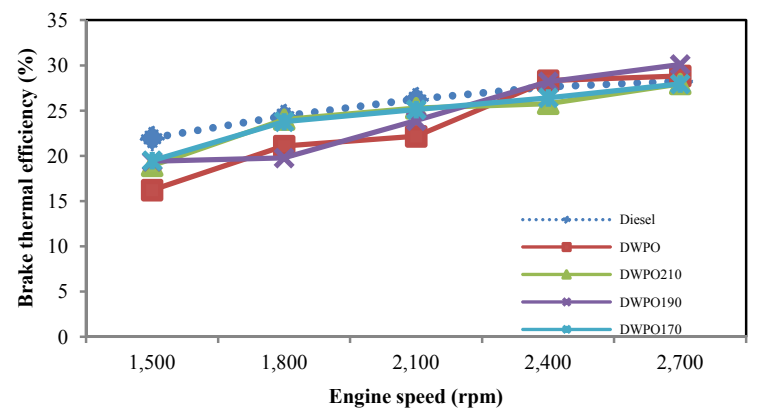

Fig. 3. Compares of brake thermal efficiency with engine speed 


\section{Brake specific Fuel Consumption}

Fig. 4 Compares the influence of nozzle pressure in compression ignition engine running diesel oil and distilled waste plastic oil (DWPO) with standard nozzle pressure and setting nozzle pressure at 170,190 and 210 bar on brake specific fuel consumption. It shows the comparison of the brake specific fuel consumption is $0.28 \mathrm{~kg} / \mathrm{kWh}$ at higher engine speed for diesel with standard nozzle pressure and shows that the engine running with distilled waste plastic oil (DWPO) at standard nozzle pressure and setting nozzle pressure at 170,190 and 210 bar gives brake specific fuel consumption is $0.27 \mathrm{~kg} / \mathrm{kWh}, 0.28 \mathrm{~kg} / \mathrm{kWh}, 0.26 \mathrm{~kg} / \mathrm{kWh}$ and $0.28 \mathrm{~kg} / \mathrm{kWh}$ respectively at higher engine speed. Average of the brake specific fuel consumption is $0.31 \mathrm{~kg} / \mathrm{kWh}$ at for diesel with standard nozzle pressure and with distilled waste plastic oil (DWPO) at standard nozzle pressure and setting nozzle pressure at 170,190 and 210 bar gives average brake specific fuel consumption is $0.35 \mathrm{~kg} / \mathrm{kWh}, 0.32 \mathrm{~kg} / \mathrm{kWh}, 0.33$ $\mathrm{kg} / \mathrm{kWh}$ and $0.33 \mathrm{~kg} / \mathrm{kWh}$ respectively. This result is a higher average in brake specific fuel consumption for distilled waste plastic oil (DWPO) but lower average when setting nozzle pressure at 170,190 and 210 bar. Because of the changes in setting nozzle pressure cause can be a better brake specific fuel consumption.

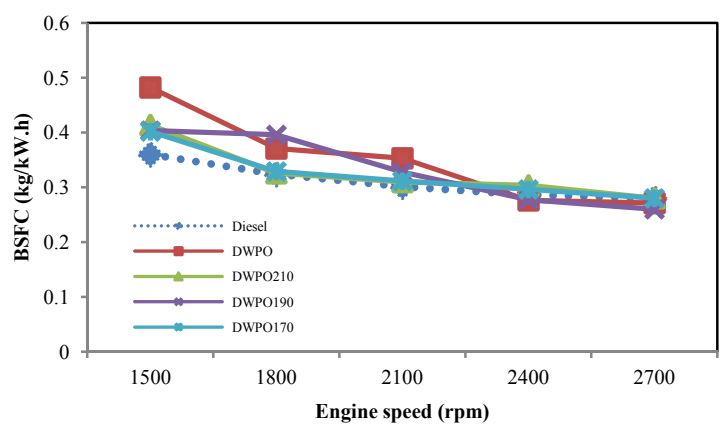

Fig. 4. Compares of brake specific fuel consumption with engine speed

\section{Exhaust Gas Temperature}

Fig. 5 Compares the influence of nozzle pressure in compression ignition engine running diesel oil and distilled waste plastic oil (DWPO) with standard nozzle pressure and setting nozzle pressure at 170,190 and 210 bar on exhaust gas temperature. It shows the comparison of the exhaust gas temperature ranges from $245^{\circ} \mathrm{C}$ at low engine speed to $523^{\circ} \mathrm{C}$ at high engine speed for diesel with standard nozzle pressure and shows that the engine running with distilled waste plastic oil (DWPO) at standard nozzle pressure and setting nozzle pressure at 170,190 and 210 bar gives exhaust gas temperature ranges from $220^{\circ} \mathrm{C}$ at low engine speed to $490^{\circ} \mathrm{C}$ and at high engine speed for distilled waste plastic oil (DWPO) at standard nozzle pressure and ranges from $232^{\circ} \mathrm{C}$ at low engine speed to $480^{\circ} \mathrm{C}$ at high engine speed, $258^{\circ} \mathrm{C}$ at low engine speed to $460^{\circ} \mathrm{C}$ at high engine speed, $243^{\circ} \mathrm{C}$ at low engine speed to $450^{\circ} \mathrm{C}$ at high engine speed at setting nozzle pressure at 170,190 and 210 bar respectively. The average of exhaust gas temperature is $360^{\circ} \mathrm{C}$ for diesel with standard nozzle pressure and distilled waste plastic oil (DWPO) at standard nozzle pressure and setting nozzle pressure at 170,190 and 210 bar gives an average exhaust gas temperature is $350^{\circ} \mathrm{C}, 367^{\circ} \mathrm{C}, 389^{\circ} \mathrm{C}$ and $355^{\circ} \mathrm{C}$ respectively.
This result is a lower average in exhaust gas temperature for distilled waste plastic oil (DWPO) and setting nozzle pressure at 170,190 and 210 bar. Because the fuel spray becomes finer and effective combustion takes place in setting nozzle pressure cause a better exhaust gas temperature.

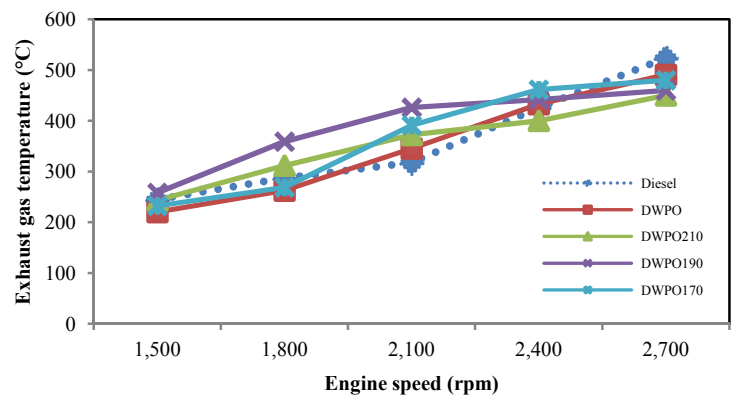

Fig. 5. Compares of exhaust gas temperature with engine speed

\section{E. Oxides of Nitrogen}

Fig. 6 Compares oxides of nitrogen $\left(\mathrm{NO}_{\mathrm{x}}\right)$ emissions with engine speed for the influence of nozzle pressure in compression ignition engine running diesel oil and distilled waste plastic oil (DWPO) with standard nozzle pressure and setting nozzle pressure at 170,190 and 210 bar. The oxides of nitrogen $\left(\mathrm{NO}_{\mathrm{x}}\right)$ emission in case of diesel with standard nozzle pressure operation ranges from 598 ppm at low engine speed to $792 \mathrm{ppm}$ at high engine speed and shows that the engine running with distilled waste plastic oil (DWPO) at standard nozzle pressure and setting nozzle pressure at 170,190 and 210 bar gives oxides of nitrogen $\left(\mathrm{NO}_{\mathrm{x}}\right)$ emission ranges from $388 \mathrm{ppm}$ at low engine speed to $721 \mathrm{ppm}$ at high engine speed for distilled waste plastic oil (DWPO) at standard nozzle pressure and ranges from $367 \mathrm{ppm}$ at low engine speed to $670 \mathrm{ppm}$ at high engine speed, $223 \mathrm{ppm}$ at low engine speed to $560 \mathrm{ppm}$ at high engine speed, $250 \mathrm{ppm}$ at low engine speed $350 \mathrm{ppm}$ at high engine speed when setting nozzle pressure at 170,190 and 210 bar respectively. The average in oxides of nitrogen $\left(\mathrm{NO}_{\mathrm{x}}\right)$ is $810 \mathrm{ppm}$ for diesel with standard nozzle pressure and distilled waste plastic oil (DWPO) at standard nozzle pressure and setting nozzle pressure at 170,190 and 210 bar gives average oxides of nitrogen $\left(\mathrm{NO}_{\mathrm{x}}\right)$ is $717 \mathrm{ppm}, 529 \mathrm{ppm}, 441 \mathrm{ppm}$ and $299 \mathrm{ppm}$ respectively. CI engines are always run lean and emit high amounts of oxides of nitrogen $\left(\mathrm{NO}_{\mathrm{x}}\right)$. [6], [7] When the engine running distilled waste plastic oil (DWPO) with standard nozzle pressure and setting nozzle pressure at 170,190 and 210 bar a decrease in the oxides of nitrogen $\left(\mathrm{NO}_{\mathrm{x}}\right)$ emissions at all the engine speed observed. Consequently the oxides of nitrogen $\left(\mathrm{NO}_{\mathrm{x}}\right)$ emission tends to be less.

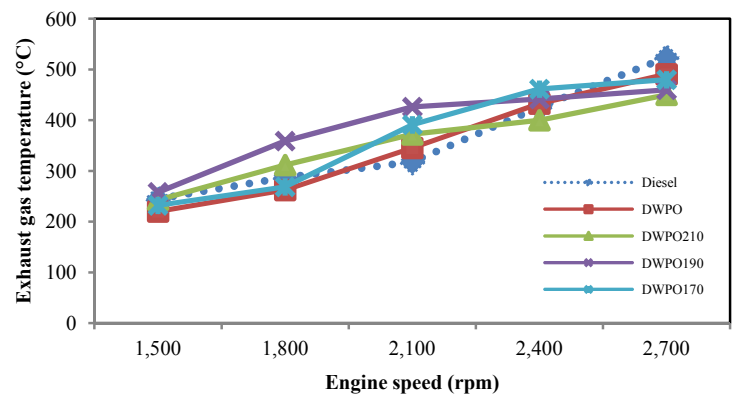

Fig. 6. Compares of oxides of nitrogen $\left(\mathrm{NO}_{\mathrm{x}}\right)$ with engine speed 


\section{F. Carbon monoxide}

Fig. 7 Compares carbon monoxide (CO) emissions with engine speed for the influence of nozzle pressure in compression ignition engine running diesel oil and distilled waste plastic oil (DWPO) with standard nozzle pressure and setting nozzle pressure at 170,190 and 210 bar. The carbon monoxide (CO) emissions in the case of diesel from $0.07 \%$ vol. at low engine speed to $0.20 \%$ vol. at high engine speed and shows that the engine running with distilled waste plastic oil (DWPO) at standard nozzle pressure and setting nozzle pressure at 170,190 and 210 bar gives carbon monoxide (CO) emissions a range from $0.05 \%$ vol. at low engine speed to $0.11 \% \mathrm{vol}$. at high engine speed for distilled waste plastic oil (DWPO) show ranges from $0.05 \%$ vol. at low engine speed to $0.14 \%$ vol. at high engine speed, $0.05 \%$ vol. at low engine speed to $0.13 \%$ vol. at high engine speed, $0.06 \%$ vol. at low engine speed to $0.10 \%$ vol. at high engine speed when setting nozzle pressure at 170,190 and 210 bar respectively. The average of carbon monoxide (CO) is $0.09 \% \mathrm{vol}$. for diesel and distilled waste plastic oil (DWPO) at standard nozzle pressure and setting nozzle pressure at 170,190 and 210 bar gives average carbon monoxide (CO) is $0.09 \%$ \%ol., $0.08 \%$ vol., $0.08 \%$ vol. and $0.08 \%$ vol. respectively. The emissions of carbon monoxide (CO) were lower average for distilled waste plastic oil (DWPO) in a standard nozzle pressure and setting nozzle pressure at 170,190 and 210 bar operation.

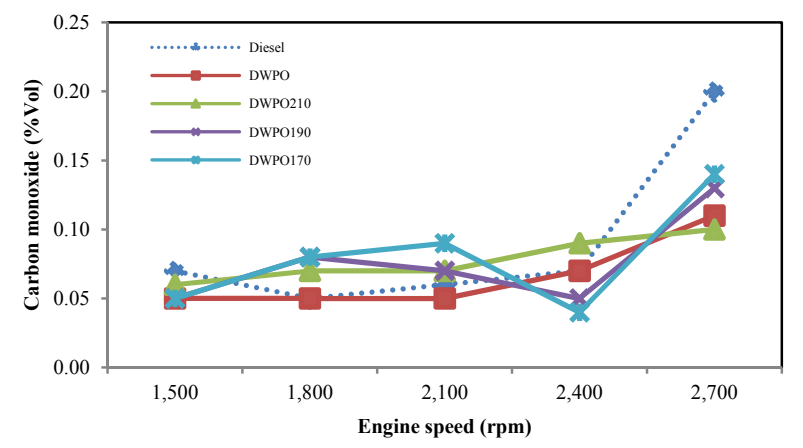

Fig. 7. Variation of carbon monoxide (CO) with engine speed

Emissions of CO from a diesel engine mainly depend on the physical and chemical properties of the fuel, air-fuel ratio and engine temperature, deficiency of oxygen and the fact that less time is available for the completion of combustion, all of which cause incomplete combustion. Air-fuel ratio is the most essential parameter which leads to emissions of $\mathrm{CO}$ [8].

\section{G. Carbon dioxide}

Fig. 8 Compares of carbon dioxide $\left(\mathrm{CO}_{2}\right)$ emissions with engine speed for the influence of nozzle pressure in compression ignition engine running diesel oil and distilled waste plastic oil (DWPO) with standard nozzle pressure and setting nozzle pressure at 170,190 and 210 bar. The carbon dioxide $\left(\mathrm{CO}_{2}\right)$ emission in case of diesel is from $3.78 \% \mathrm{vol}$. at low engine speed to $10.24 \% \mathrm{vol}$. at high engine speed and shows that the engine running with distilled waste plastic oil (DWPO) at standard nozzle pressure and setting nozzle pressure at 170,190 and 210 bar gives carbon dioxide $\left(\mathrm{CO}_{2}\right)$ emission ranges from $2.45 \% \mathrm{vol}$. at low engine speed to $8.84 \%$ vol. at high engine speed for distilled waste plastic oil
(DWPO) show ranges from $2.78 \%$ vol. at low engine speed to $7.20 \%$ vol. at high engine speed , $2.36 \%$ vol. at low engine speed to $6.25 \% \mathrm{vol}$. at high engine speed, $2.78 \% \mathrm{vol}$. at low engine speed to $4.50 \%$ vol. at high engine speed at setting nozzle pressure at 170,190 and 210 bar respectively. The average of carbon dioxide $\left(\mathrm{CO}_{2}\right)$ is $6.74 \% \mathrm{vol}$. for diesel and distilled waste plastic oil (DWPO) at standard nozzle pressure and setting nozzle pressure at 170,190 and $210 \mathrm{bar}$ gives average carbon dioxide $\left(\mathrm{CO}_{2}\right)$ is $6.12 \%$ vol., $4.83 \%$ vol., $4.12 \%$ vol. and $2.99 \%$ vol. respectively. The emissions of carbon dioxide $\left(\mathrm{CO}_{2}\right)$ were lower for distilled waste plastic oil (DWPO) at standard nozzle pressure and setting nozzle pressure at 170,190 and 210 bar operation. This is due to the instability in combustion and deficiency of oxygen that makes the $\mathrm{CO}$ concentration to increase and $\mathrm{CO} 2$ concentration to decrease [9], [10]

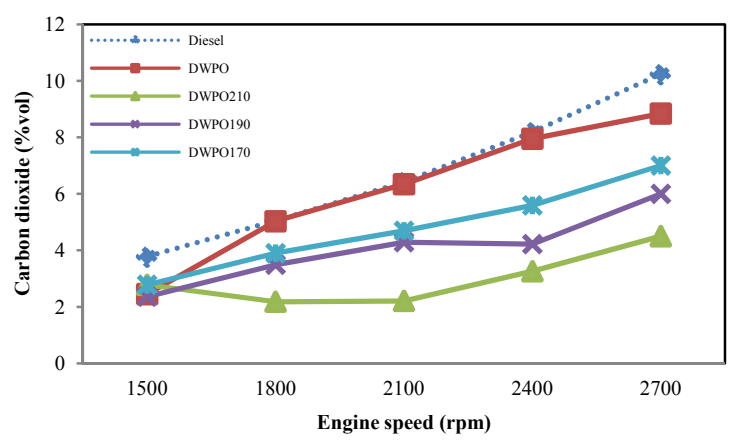

Fig. 8. Variation of carbon dioxide $\left(\mathrm{CO}_{2}\right)$ with engine speed

\section{CONCLUSION}

From the tests conducted with diesel oil and distilled waste plastic oil (DWPO) with standard nozzle pressure and setting nozzle pressure at 170,190 and 210 bar on a compression ignition engine, the following conclusions are derived. Compression ignition engine was able to run with distilled waste plastic oil. Physical characteristics of distilled waste plastic oil (DWPO) is similar to diesel oil. Engine fueled with distilled waste plastic oil exhibits lower brake thermal efficiency but increase average when setting nozzle pressure and results are higher than average in brake specific fuel consumption for distilled waste plastic oil (DWPO) but lower average when setting nozzle pressure. Exhaust gas emission increase average when setting nozzle pressure in distilled waste plastic oil (DWPO) compared to diesel operation and results are that the nozzle setting pressure can help reduced emissions better.

\section{ACKNOWLEDGMENT}

The author thanks the Energy Policy \& Planning Office (EPPO), Ministry of Energy, Thailand for the financial grant in $\mathrm{PhD}$ course; Department of Auto Mechanical, Ubonratchathani technical college, Thailand for the engine tests.

\section{REFERENCES}

[1] R. Tubnonghee et al., "Comparision of Characteristics and Qualities of Pyrolytic Oil and Distilled Pyrolytic Oil from Municipal Plastic Wastes Case Study: Warinchamrap Municipality," presented at the Social-Energy-Environmental Development: SEED towards Sustainability, pp. 16-18, Nov, 2011. 
[2] P. T. Williams and E. A. Williams, "Interaction of plastics in mixed plastics pyrolysis," Journal of Energy and Fuels, vol. 13, pp. 188-196, 1990.

[3] M. Mani and G. Nagarajan, "Influence of injection timing on performance, emission and combustion characteristics of a DI diesel engine running on waste plastic oil," Journal of energy, vol. 34, pp. $1617-1623,2009$.

[4] The Siam Kubota industry co. 1td., Operation and maintenance manual Kubota, 2009

[5] Notification of Department of Energy Business, Prescribing the Characteristic and Quality of Diesel Oil (No.5) B.E. 2011.

[6] J. B. Heywood, Internal combustion engine fundamentals, McGraw-Hill, New York, 1989.

[7] M. Mani, C. Subash, and G. Nagarajan, "Performance, emission and combustion characteristics of a DI diesel engine using waste plastic oil," Journal of applied Thermal Engineering, vol. 29, pp. 2738-2744, 2009.

[8] O. Arpa, R. Yumrutaş, and Z. Argunhan, "Experimental investigation of the effects of diesel-like fuel obtained from waste lubrication oil on engine performance and exhaust emission," Journal of Fuel Processing Technology, vol. 91, pp. 1241-1249, 2010.
[9] M. Mani, G. Nagarajan, and S. Sampath, "An experimental investigation on a DI diesel engine using waste plastic oil with exhaust gas recirculation," Journal of fuel, vol. 89, pp. 1826-1832, 2010.

[10] M. Mani, G. Nagarajan, and S. Sampath, "Characterisation and effect of using waste plastic oil and diesel fuel blends in compression ignition engine," Journal of energy, vol. 36, pp. 212-219, 2011.

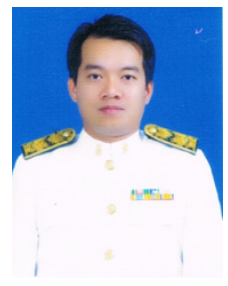

Chumsunti Santaweesuk was born on June 1, 1976. He received Degree of Mechanical Engineering, Major Mechanical Engineering, Department of Mechanical Engineering, Faculty of Engineering, Ubon Ratchathani University, Ubonratchathani, Thailand. Date of Graduation was May 28 2007. He is present Ph.D. student major in Mechanical Engineering, Ubon Ratchathani University, Thailand. Thailand. And working in Ubonratchathani technical college,

He has military and work experience, including summer and fellowship jobs. 